\title{
GRIEKSE DRAMA IN DIE MODERNE WÊRELD
}

\author{
B van Zyl Smit (Universiteit van Nottingham)
}

My onderwerp is deel van wat dikwels beskou word as die jongste vertakking van die studie van die antieke wêreld - die studie van die resepsie van die antieke. ${ }^{1}$ Hierdie studie ondersoek hoe later omgegaan is met tekste of voorwerpe uit die Klassieke oudheid. Soos my titel, 'Griekse drama in die moderne wêreld', aandui, fokus ek op 'n spesifieke deel van die letterkunde van die antieke Grieke, naamlik drama.

Griekse drama as genre het drie vertakkings, die bekendste is tragedie en komedie, maar daar is nog 'n derde, saterspel, ${ }^{2}$ waarvan daar baie min dramas oorgebly het en wat dus nie soveel belangstelling en navolging gehad het nie, maar waarvan ek ook een voorbeeld bespreek.

Al drie hierdie vorms van drama het hul hoogtepunt gehad in die stadstaat Athene in die vyfde eeu voor Christus. Jaarliks by feeste ter ere van Dionusos wat nie net die god van wyn was nie, maar ook van drama, is nuwe stukke in 'n kompetisie opgevoer. Drie tragiese digters is jaarliks gekies om elk 'n trilogie van tragedies te produseer, gevolg deur 'n saterspel. Wat komedie betref, was daar jaarliks vyf. Al drie genres het in gemeen gehad dat 'n koor 'n integrale deel van die struktuur gevorm het. Dit is 'n aspek van die antieke stukke wat dikwels probleme aan latere regisseurs en verwerkers verskaf.

Dit is merkwaardig dat ' $n$ handvol toneelstukke wat oorspronklik geskryf is om eenmalig opgevoer te word by ' $n$ religieuse fees twee en 'n half millennia gelede oorleef het tot in die hede, en nie net oorleef het nie, maar ontelbare kere weer opgevoer is, vertaal is, en verwerk is en veral sedert die twintigste eeu, opgevoer is dwarsoor die wêreld. Hierdie fenomeen is natuurlik al deeglik ondersoek deur akademici wat hulle toespits op die studie van resepsie. Dit is redelik maklik om antwoorde te vind op die vrae van watter dramas die meeste invloed uitgeoefen het, waar en wanneer dit gebeur het en hoe dit geskied het, maar die een knaende vraag waarop niemand 'n eenvoudige antwoord kan verskaf nie, is waarom? Ek hoop om deur drie voorbeelde te bespreek, 'n paar van die redes vir hierdie buitengewone lewenskragtigheid van die Griekse drama te suggereer.

My voorbeelde verteenwoordig die drie genres van antieke drama: tragedie, komedie en saterspel. As voorbeeld van tragedie bespreek ek 'n Romeinse stuk, al klaar 'n geval van resepsie. Dit is die Thyestes van Lucius Annaeus Seneca wat in die eerste eeu n.C. geleef het. Alhoewel ons weet dat verskeie ander Griekse en

$\begin{array}{ll}1 & \text { Sien Hardwick 2003 vir 'n oorsig oor die studie van die resepsie van die Klassieke. } \\ 2 & \text { Sommerstein 2002:22-25 bied 'n bondige oorsig oor die kenmerke van die saterspel. }\end{array}$ 
Romeinse digters dramas oor hierdie mite geskryf het, is Seneca se weergawe al een wat ons vandag nog het. As voorbeeld van komedie neem ek die Voëls van die Griekse komediedigter Aristophanes, wat in Athene se bloeitydperk nie net die gek geskeer het met politici van sy tyd nie, maar ook ernstige krisisse aangeroer het. As voorbeeld van saterspel ondersoek ek die fragmente van Sophokles se Ichneutai, Die spoornyers. Vir elk van hierdie stukke het ek 'n voorbeeld van hulle resepsie gekies: vir Thyestes die toneelstuk met dieselfde naam van die Vlaamse skrywer, Hugo Claus; vir Voëls André P Brink se Die hand vol vere, en vir saterspel die Egiptiese skrywer Ahmed Etman se Bokke van Albahnasa, met as addisionele interteks die Engelse dramaturg Tony Harrison se Trackers of Oxyrhynchus. Met hierdie keuse dek ek hopelik die drie rigtings van die Universiteit van Stellenbosch se Department van Antieke Studie - Romeins, Grieks en Semitistiek.

Eerstens tragedie. Seneca se Thyestes gaan oor 'n deel van die mite van die huis van Atreus, die koning van Argos en vader van twee van die Griekse helde in Homerus se Ilias, naamlik Agamemnon en Menelaus. Die deel van die mite wat Seneca gedramatiseer het, behandel 'n vroeëre episode uit die gekiedenis van hierdie besondere wanangepaste en bloeddorstige familie. Atreus en Thyestes is twee broers, die seuns van Pelops wat deur sy vader Tantalus as maaltyd aan die gode voorgesit is. Hiervoor is Tantalus verdoem om vir ewig in die onderwêreld honger en dors te ly met voedsel en water wat altyd net buite sy bereik bly. Pelops is deur die gode weer lewendig gemaak, maar sy bestaan het baie gruweldade ingesluit en na sy dood het die familievloek oorgegaan op sy seuns, Atreus en Thyestes. Hulle ooreenkoms om die koningskap te deel of om die beurt te regeer, is herhaaldelik verbreek en elk van die broers was by tye koning en by tye in ballingskap. Die tragedie speel af met Atreus op die troon en besig om 'n plan te beraam om wraak te neem op Thyestes wat voorheen die koningskap geniet het, o.a. deur Atreus se vrou af te rokkel. Atreus se plan is om voor te gee dat hy 'n finale versoening wil bewerkstellig. Hy nooi dus Thyestes om terug te keer en die koningskap met hom te deel.

Seneca se tragedie begin met 'n proloog waarin die skim van Tantalus verskyn. Hy is uit die Onderwêreld gesleep deur 'n Furie, 'n wrakgodin, om die huis van sy nageslag te besmet met sy misdadige neigings en te verseker dat die siklus van wandade voortgaan. 'n Atmosfeer van onheil en vrees word geskep want Tantalus, self 'n geharde wreedaard, is angsbevange oor wat die Furie beplan. Alhoewel hy homself probeer verset teen haar, moet hy swig en sy vloek oor die paleis versprei. Hierdie opening word gevolg deur 'n koorlied waarin die koor van die ou mans van Argos die verskriklike geskiedenis van die koningshuis vertel en bid dat daar nou 'n einde aan die haat sal kom. Soos dikwels in Seneca se tragedies, is die koor skynbaar nie bewus van wat in die tonele afspeel nie. 
Die daaropvolgende toneel, tussen Atreus en 'n vertroueling, is dan ook in skerp teenstelling met hierdie hoop op vrede. Atreus is duidelik 'n magbeluste tiran. Hy beplan sy wraak hardop, dit moet so afgryslik wees dat dit Thyestes sal breek. Die vertroueling se pogings om hom daarvan te laat afsien deur byvoorbeeld te sê dat hy die steun van sy volk sal verloor as gevolg van die monsteragtige dade wat hy beplan, is tevergeefs. Atreus skep behae daarin deur te vertel hoe hy 'n lokval vir Thyestes gaan stel deur hom te nooi om terug te kom na Argos toe om met hom die koningskap te deel.

Die koorlied wat volg druk hulle vreugde uit oor die versoening tussen die broers. Hulle reaksie is die van gewone mense wat die nuus van Atreus se uitnodiging aan sy broer om versoening gehoor het. Die koor gee ook hulle opvatting van wat 'n ideale regeerder is. Hulle beklemtoon dat dit nie uiterlike vertoon, 'n kroon, rykdom en 'n goudbelaaide paleis is wat 'n koning maak nie; 'n ware koning is 'n mens wat sonder vrees leef, wie se hande onskuldig is en wie se gewete skoon is. Hierdie definisie van 'n koning stem ooreen met die van die Stoïsynse filosofiese siening van 'n wyse man. Behalwe as dramaskrywer, is Seneca veral bekend as skrywer wat in 'n hele aantal prosawerke, die Stoïsynse filosofie uiteengesit het. Daar is geleerdes wat Seneca se tragedies ook interpreteer as propagandastukke vir Stoïsisme, maar myns insiens is so ' $n$ interpretasie moeilik bewysbaar. Wat van belang is in die Thyestes, is dat die beskrywing van die ideale regeerder, kennelik in lynregte teenstelling is met Atreus, die koning wat in die vorige toneel verskyn het. Hier kan Seneca se eie rol as leermeester en raadgewer van keiser Nero ook in ag geneem word. Nero was maar sestien toe hy in 54 n.C. keiser geword het en tydens die eerste vyf jaar van sy bewind het Seneca saam met die militêre bevelvoerder, Burrus, deels die Romeinse Ryk bestuur en sy leerling probeer onderrig hoe om 'n regverdige regeerder te wees. Ongelukkig was Nero nie 'n goeie leerling nie. Hy het sy stiefbroer en sy eie ma laat vermoor. Seneca self het familiegeweld en haat dus van baie naby beleef. ${ }^{3}$

$\mathrm{Na}$ die tema van heerserskap in die drama aangeroer is, kom Thyestes, die ander aanspraakmaker op die koningskap, op die toneel. Hy is vergesel van sy drie seuns. Hy het Atreus se boodskap gekry en is op pad na Argos. Tog is Thyestes onrustig. Hy wil graag glo dat alles nou goed sal gaan maar kan sy twyfel en agterdog nie heeltemal baasraak nie. In voorkoms is Thyestes 'n karikatuur van die algemene opvatting van 'n filosoof. Sy klere is verslons en armoedig, sy hare en baard vuil. In dialoog met sy seuns wat gretig is dat hy Atreus se aanbod moet aanvaar en weer koning word, uiter hy soortgelyke gedagtes as die van die koor, naamlik dat slegs innerlike mag die moeite werd is en dat koningskap hom aan

Tacitus Ann. 12-14 beskryf die gebeure aan die hof van Nero. 
gevaar sal blootstel. Hierdie opvatting word vervat in sogenaamde sententiae, pittige stellings wat algemene waarhede uitdruk. So sê Thyestes:

Misdade kom nie in arm huisies nie (scelera non intrant casas 451).

Gif word bedien in goue drinkbekers (venenum in auro bibitur 453).

Gemoedsrus is groot na gelang vermoë klein is (rebusque parvis magna praestatur quies 469 ).

Dat hierdie 'n poging is om ook homself te oortuig, word bewys wanneer hy deur Atreus ontvang word en swig voor die verlokking om weer die weelde en mag te deel. Thyestes gee homself totaal in Atreus se mag oor. Hy aanvaar sy aanbod om saam te regeer, hy bely sy skuld teenoor Atreus dat hy hom in die verlede onreg aangedoen het en vertrou selfs sy kinders aan hom toe.

Die gehoor weet nou dat Atreus se afgryslike wraakplanne in werking gestel is. In kontras sing die koor oor hulle vreugde dat daar vrede is tussen die broers. Hulle sluit egter af met ' $n$ bevraagtekening van die (on)voorsienigheid en die wispelturige aard van van Fortuin.

Dit skakel goed met die verskyning van 'n boodskapper wat oorstelp is deur die gruwelverhaal wat hy het om te vertel. Die koor moet hom eers kalmeer voor hy 'n gedetailleerde verslag lewer van hoe Atreus Thyestes se seuns geslag en geoffer het. Ek gebruik die woord 'slag' doelbewus want dit is die vreesaanjaende storie wat die boodskapper as ooggetuie aan die koor en die gehoor vertel. Atreus het sy drie nefies soos offerdiere met kranse en offermeel versier voor hy hulle kele afgesny het op die altaar. Atreus het self as priester opgetree, gebede geuiter en die mes hanteer. Die boodskapper se verslag vergelyk Atreus eers met 'n tier en dan met 'n leeu om sy onmenslike koelbloedigheid en wreedheid oor te dra. Sy perversiteit blyk verder daaruit dat hy nie net die priester is nie, maar ook die god aan wie die offerande gewy word. Dit was egter net die eerste stap. Daarna sny Atreus die kinders se koppe en hande af, sit hulle eenkant en sny dan die res van hul liggame op en kook party dele in koperpotte, terwyl hy ander op spitte braai oor die vuur. Die boodskapper gaan onmiddellik van hierdie grusame beskrywing oor na 'n nog meer groteske: hoe Thyestes, hierdie maaltyd eet, onbewus dat dit sy eie kinders is. Thyestes is aangetrek in koningsklere wat Atreus aan hom gegee het, sy hare is geparfumeer en hy dra 'n feeskrans. Hy is goed aangeklam en skep die prentjie van 'n dekadente Romein wat 'n feesmaal vier. Die boodskapper se laaste woorde is dat die enigste goeie element in Thyestes se ramp is dat hy nog onbewus is daarvan. Seneca se beskrywing van hierdie afskuwelike toneel word afgerond met die noem daarvan dat dit oordag donker geword het omdat selfs die Son teruggedraai het sodat hy nie hierdie gruwel hoef te aanskou nie. 
Die koor is so geskok dat hulle vra of die einde van die wêreld aangebreek het.

Die laaste toneel open met Atreus hoogs in sy noppies: Die woorde van sy alleenspraak weerspieël dit duidelik:

Aequalis astris gradior et cuncta super 885

altum superbo vertice attingens polum.

nunc decora regni teneo, nunc solium patris.

dimitto superos; summa votorum attigi.

Ek stap as gelyke van die sterre! Bo die wêreld reik ek trots tot by die hemel. Nou hou ek die glorie van koningskap, nou die troon van ons vader. Ek gee die gode die trekpas. Ek het die toppunt van my wense bereik.

Atreus beskryf hoe Thyestes ontnugter gaan word en verlustig hom in die sukses van sy groteske wraak. Hy verlustig hom ook in die vooruitsig op nog groter genoegdoening wanneer Thyestes besef wat hy gedoen het. Nou laat Seneca Thyestes ook sy gedagtes en gevoelens uiter. Alhoewel hy met alle eer deur Atreus ontvang is en op die feesmaal getrakteer is, voel hy tog onrustig en ongelukkig.

Dan volg 'n dialoog tussen die broers waarin Atreus op sadistiese wyse Thyestes met dubbelsinnighede om die bos te lei. Die klimaks kom wanneer hy Thyestes se seuns se koppe en hande tevoorskyn bring en hulle vader daarmee konfronteer. As Atreus tartend vra: 'Herken jy jou seuns?' , antwoord Thyestes: 'Ek herken my broer'. (A.: natos ecquid agnoscis tuos? 1005. T.: agnosco fratrem.)

Dit is die oomblik van waarheid waar al sy vrese as gegrond bewys word en hy besef dat Atreus nog wreder en meer wraakbelus is as wat hy hom enigsins kon voorgestel het.

Atreus is nog nie tevrede nie, maar hy hou aan om sy broer te treiter en toon geen teken van berou nie. Hy wens selfs dat hy Thyestes nog meer kon folter. Thyestes daarenteen is hulpeloos. Hy beroep hom op die gode om Atreus se boosheid te straf, maar Atreus se antwoord is dat hy Thyestes aan sy kinders oorgee as straf.

Hierdie skokkende verhaal vertolk die mite, maar Seneca het dit op meesterlike wyse gestruktureer om die gruwel te beklemtoon. Waarom? In die moderne tyd is Seneca se tragedies dikwels gekritiseer omdat hulle soveel geweld en gruwel beskryf, maar in die twintigste eeu het letterkundiges en klassici hulle met nuwe insig begin bestudeer en besef dat hulle nie altyd met Griekse tragedies vergelyk moet word nie, maar as werke in eie reg benader moet word. Een van die eerstes wat dit gedoen het, was T S Eliot in 'n toonaangewende essay in 1927 wat 
hy geskryf het as inleiding vir 'n heruitgawe van die eerste Engelse vertalings van al Seneca se tragedies in 1581. 'n Ander belangrike bydrae tot die herinterpretasie van Seneca se werk was die van die Franse digter en teoretikus Antonin Artaud. Hy het spesifiek die Thyestes uitgesonder as 'n toneelstuk wat perfek pas in sy konsepsie van die 'Teater van Wreedheid'. Artaud het beplan om sy verwerking van die drama op te voer maar het nooit so ver gekom nie. Sy entoesiastiese reklame vir die stuk, het egter 'n aantal ander skrywers beïnvloed, onder andere die jong Vlaamse digter Hugo Claus. Dit is in sy verwerking van die Thyestes dat ' $\mathrm{n}$ mens 'n oortuigende verklaring kan vind vir die uitbeelding van wat met die eerste oogopslag mag voorkom as nodelose gruwel en geweld.

Claus het erken dat dit juis die kwaliteite van Seneca se tragedies was wat deur ander gekritiseer is wat hom aangetrek het. Hy het 'n verband gesien tussen wat hy beskryf het as 'goedkoop sensasionalisme, met oordadige gruwel en grandguignol'4 en die sensasiewekkende koerantverslae van moorde en ongelukke in die moderne wêreld.

Claus was self die regisseur toe sy verwerking van Thyestes in 1966 in Brussel op die planke gebring is. Hy het die geleentheid gebruik om 'n Gesamtkunstwerk te skep, waarvan elke aspek van die opvoering — beweging, musiek, verhoogontwerp, diksie en spel in oorenstemming met sy konsep was. Hierdie konsep van totale teater was ook in lyn met Artaud se idees. Elemente daarvan is die gebruik van ongewone musiekinstrumente, voorwerpe van ongewone grootte soos die enorme troon wat die verhoog in Claus se toneel oorheers het, en spraak as 'n soort inkantasie. Die verhoog in Claus se produksie is gedomineer deur 'n reusagtige troon wat die koningsmag wat sentraal in die drama is, simboliseer. Claus het verduidelik dat dit so groot is dat niemand gemaklik daarop kan gaan sit nie maar op 'n onwaardige manier moet opklouter.

Claus bly baie na aan die struktuur van Seneca se drama maar verkort van die lang monoloë, en laat meer obskure vewysings na die mitologie uit. In plaas van 'n koor het hy een man wat die rol vertolk, 'n jong man met geen besondere kenmerke nie en wie die verkorte koorliedere redelik toonloos voordra. Die skim van Tantalus in die openingstoneel is 'n logge gestalte wat lyk of dit lank in die water was en die Furie 'n verleidelike jong vrou, skamel geklee.

Uit Claus se programnotas, asook uit kontemporêre resensies is dit duidelik dat hierdie produksie surrealisties eerder as realisties was. Na aanleiding van die byna onuitspreeklike sadisme en gruwel van die Thyestes mite, Atreus se wreedaardige wraak met die slagting van sy broer se kinders en die manier waarop hy sy broer 'n onwetende kannibaal maak wie sy eie kinders verorber, vra Claus in die programnotas: Die tragiese swart held, die retoriese manier van kommunikeer,

$4 \quad$ My vertaling van Claus se programnota by die opvoering van Thyestes in 1966. 
die sensasionalisme, die bloed en bloeddorstigheid, en dit alles onderbreek deur 'n moraliserende boodskap, wat is nader aan die koerante van vandag?

Claus neem Atreus se laaste woorde uit Seneca oor, dat hy Thyestes oorlewer aan sy kinders vir wraak, maar dan is daar 'n verrassende toneelaanwysing: 'omstrengeld, soos twee minnaars, bly hulle onbeweeglik' (p. 69). ${ }^{5}$ Waarom sou die twee broers, sulke toonbeelde van haat, die een 'n sadis en die ander sy slagoffer, mekaar nou soos minnaars omhels? Terwyl hulle so in die omhelsing staan, klim Tantalus in die agtergrond weer op die troon - 'n duidelike aanduiding dat die opeenvolging van geweld nog nie tot 'n einde gekom het nie, dat die siklus voortduur - en die koor voeg die volgende verse wat nie in die antieke drama is nie, maar deur Claus geskryf is, by:

So was dit. En dit sal nie anders wees nie.

Nutteloos wentel die geweldige wiel deur die tyd,

Dink aan die families wat mekaar verskeur, aan verbrande paleise,

Koninkryke wat verdwyn soos dou, aan die steeds swygende,

Steeds vlugtende gode, aan die volke wat gefolter word en geslag soos skape. Voortdurend word die natuur geskend,

Bloed vemeng in kwaad en in wellus, vinniger in wellus,

En die vrae bly dieselfde

Vir wurms soos vir mense.

En nog altyd bedek die nag die aarde nie met haar dodelike, dikke wolke nie.

Hierdie wanhopige, pessimistiese slot brei die siklus van geweld en slagting tot 'n globale skaal uit. In sy programnota dui Claus aan dat in 1966 die apokaliptiese einde van die drama, die onbestrafte misdade en die terugkeer na chaos nie so vergesog lyk nie. Die drama reflekteer die somber atmosfeer van die hoogtepunt van die Koue Oorlog toe baie mense 'n kernkatastrofe gevrees het, maar hierdie einde het ook iets tydloos en kan toegepas word op die inherente boosheid van die mensdom in ons betrekkinge met ons medemense en ons houding teenoor die natuur en die aarde. Dit is hierdie wysigings en toevoegings wat Claus se estetiese verandering van die antieke tragedie beklemtoon en die verplasing na die moderne wêreld onderstreep waar daar geen gode is nie en waar mense mekaar ongestraf vermoor en folter. Die verhoogaanwysing dat die twee broers mekaar omhels en roerloos so staan aan die einde, 'soos twee minnaars' toon dat hulle twee kante van dieselfde boosheid is, dat hulle aan mekaar verbind is deur hulle kwaadaardigheid. Dit is nou amper vyftig jaar vandat Claus hierdie toneelstuk geskryf het en dis nie moeilik om sy vertolking toe te pas op ons eie tydperk nie.

Vertalings van Claus se werk is deur die skrywer van hierdie artikel. 
Maar genoeg van swartgalligheid. Die tweede voorbeeld wat ek wil bespreek is die verwerking van Aristophanes se Voëls. Hierdie komedie is die eerste keer opgevoer in Athene in 414 v.C. Die naam kom van die koor van voëls. Anders as in tragedies waarvan die intriges meestal op mites gebaseer is, het komedieskrywers hulle eie stories gemaak. In Voëls is twee ouer Atheense mans, Peisisthetairos en Euelpides, op soek na 'n nuwe stad. Hulle het Athene verlaat omdat hulle moeg was vir die konstante struwelinge, belastings en so meer. Hulle loop die Hoep-hoep raak. Hy was eers 'n mens en verstaan mense se taal. Peisisthairos stel voor dat die voëls 'n stad in die lug moet stig om heersers van die heelal te word. Die Hoep-hoep roep al die voëls bymekaar en alhoewel hulle eers die mense wil aanval, praat Peisisthetairos hulle om deur te belowe dat hy vir hulle die heerserskap oor die heelal sal terugwen wat, soos hy sê, eers aan hulle behoort het, voor die gode dit afgeneem het. Die voëls aanvaar sy voorstel om 'n stad tussen die gode en die mense te stig. Die belangrikheid van voëls vir alle menslike aktiwiteite word beklemtoon. Daar sal volkome geluk en vrede wees as mense voëls sou aanbid. Peisisthetairos en Euelpides het intussen hulleself in voëls verander deur groteske vlerke aan te trek.

Die naam van die nuwe stad is Nephelokokkygia wat in Engels gewoonlik vertaal word as 'Cloudcuckooland' en deur Prof van Rensburg as 'Wolkekoekoekstad'. ${ }^{6}$ 'n Hele reeks karakters kom nou in om betrekkinge met die nuwe stad aan te knoop: 'n digter met liedere ter ere van die stad, 'n orakelsmous, 'n stadsbeplanner, 'n belastingadviseur, 'n wettesmous. Almal word weggejaag maar 'n boodskapper kom sê dat 'n god by die wagte verbygekom het en gevang is. Dit is die godin Iris wat deur Zeus gestuur is om te kla dat daar nie meer aan die gode geoffer word nie. Die voëls se nuwe stad, halfpad tussen die mense en gode, keer die gebede en offerandes van onder en die antwoorde van bo af. Peisisthetairos jaag haar weg met dreigemente, wat ook aan Zeus, die oppergod, gerig is.

Nog 'n boodskapper kom vertel dat daar 'n voëlmania onder die mense uitgebreek het. Almal wil net by hulle kom aansluit. Dan kom Prometheus aan, onder 'n sambreel sodat Zeus hom nie kan raaksien nie. Hy vertel dat die gode besig is om weg te kwyn en 'n afvaardiging gaan stuur om te onderhandel. Hy raai Peisisthetairos aan om nie net Zeus se septer te eis nie, maar ook prinses Basileia (Heerskappy) as vrou. Die afvaardiging van die gode bestaan uit Poseidon, Herakles, en Triballos, 'n barbaarse god. Na aansienlike geredekawel neem hulle Peisithetairos se voorwaardes aan en hy gaan haal sy bruid. Die komedie eindig met 'n vrolike party om die huwelik te vier.

Van Rensburg 1959:118. 
Antieke komedies word baie minder opgevoer in die moderne wêreld as tragedies. Dit word gewoonlik daaraan toegeskryf dat tragedie, op mite gebaseer, meer universeel is, terwyl komedie, veral die komedies van Aristophanes met verwysings na Atheense politiek en satire en aanvalle op kontemporêre politici, baie meer tydgebonde is. Voëls is egter 'n uitsondering, want dit is seker Aristophanes se komedie wat die minste verwysings na die politici en probleme van sy tyd het. Dit is eerder 'n fantasievlug en is makliker om aan te pas by ander tydperke. Die stuk beeld 'n verbeeldingswêreld uit met 'n ideale droomstaat waar wysheid, grasie en liefde heers. Die speelse aanslag in hierdie komedie word ook gereflekteer in die titel van André P Brink se verwerking vir die TRUK jeugteater in 1971: Die hand vol vere.

Brink volg die struktuur van Aristophanes se drama maar verander die karakters in Suid-Afrikaners en plaas die toneel êrens in Afrika. Dis duidelik 'n satire op Eerste minister B J Vorster se beleid van 'uitwaartse beweging', om kontak te maak met ander Afrikalande. Peisithetairos word Pistorius, 'n verligte, en Euelpides word Van der Merwe, 'n verkrampte. Hulle het Suid-Afrika verlaat en beweeg uitwaarts om weg te kom van droogte, belastings, huurkoopkontrakte, landbanklenings, petrolpryse, inflasie, die SAUK, immigrante en ander griewe. Hulle hoop om 'n nuwe land te vind sonder al hierdie euwels. Pistorius en Van der Merwe oortuig Koning Hoepoe dat die nuwe land 'n naam en vlag moet hê en volksfeeste waar daar langdradige toesprake gemaak kan word.

Soos in die Griekse komedie daag daar 'n reeks besoekers op en dit gee Brink die geleentheid vir satire op Suid-Afrikaners en instellings van die tydperk. Die priester is 'n parodie van 'n dominee, 'n bombastiese huigelaar wie se preek deur advertensies onderbreek word. Die digter is Wurm Wurmse, 'n karikatuur van Breyten Breytenbach. Prometheus word Promethes. Die naam suggereer die bynaam van die Nasionale party kabinetsminister Piet Koornhof, alombekend as 'Piet Promises'. Poseidon, Herakles en Triballos word vervang deur drie afgevaardigdes van die VVO, 'n duidelike verwysing na die destydse regering se beheptheid met wat bestempel is as VVO inmenging in Suid-Afrika se binnelandse beleid. Die koorsang word vervang deur populêre Afrikaanse volksmusiek.

Hierdie stuk is goed ontvang deur resensente wat dit as 'volksatire', en selfs 'n Afrikaanse weergawe van die 'rock' musiekblyspel Hair beskryf het (Eben Meiring in Die Burger, 28 Julie 1971). Daar was lof vir die ensemblespel en die speelse en gevatte teks wat die gehoor aan die lag gehou het. Maar daar was een resensent, in Die Transvaler (H J 9 April 1971), wat gekla het dat die stuk alles Brink en geen Aristophanes was nie en gevra het of dit vir Brink nodig was om agter 'n groot skrywer te skuil. Hierdie resensie toon die vyandigheid teenoor Brink van konserwatiewe Afrikaners wat geskok was deur sy gewaagde romans in die sestigerjare. 
Maar daar was nog meer vyandige reaksie toe TRUK die stuk op toer deur die platteland geneem het. Uit die Wes-Transvaal het daar woedende briewe na die koerante gekom. Ds N R Van Zyl van Christiana skryf: '[daar] is goed daarin geslaag om die seksbelaaide, vulgêre Hippiekultus van die buiteland aan ons jeug te kom opdis - in plaas van die uitbeelding van die skone, die opbouende en estetiese kunsnorme. Ons wat nog glo aan 'die erwe van ons Va'dre', kon moeilik sluk aan die klinknaelbroekies van die dames en die lang hare van die mans'. Dit is ds van Zyl se kritiek op die voorkoms van die stuk. Hy skryf ook dat hy nie kan verstaan hoe die stuk by die Publikasieraad kon verbygeglip het nie. Hy gee toe dat Die hand vol vere seker veronderstel is om satire te wees maar waarsku teen die morele gevaar wat hierdie soort opvoering inhou: 'Wat die opvoedkundige waarde (om nie eens van geestelike waarde te praat nie) van hierdie stuk is, sal ek graag wil weet'. Hy eindig met 'n beroep op ouers en die jeug van ons volk om die soort opvoering te verwerp met die veragting wat dit verdien (Die Transvaler 27 Aug. 1971).

Nog briewe aan die koerante het gevolg soos die van A M De Lange van Potchefstroom (7 Sept. 1971). Hy noem die produksie gruwelik, onrein en Godsonterend, en vaar daarteen uit op dieselfde trant as in die vorige brief, maar volgens hom is dit nog gevaarliker: 'Daar is bv. Kommunistiese breinspoelingstegnieke in die stuk toegepas' skryf hy en verdoem ook die 'vulgêre, suggestiewe, seksbelaaide danse ... op maat van psigedeliese musiek'. Hy dring aan dat TRUK moet verantwoording doen dat hulle so 'n volksvreemde stuk vir kinders opgevoer het.

'n Brief net geteken deur '"n ouer', sluit hom by die ander besware aan en val ook Brink persoonlik aan. Die brief lees: '[Die hand vol vere] kan net snaaks wees vir mense wat die Bybel verwerp het as 'n heilige Boek soos die skrywer van die betrokke stuk wat reeds in die openbaar verklaar het dat hy 'n ateïs is' (Die Transvaler 13 Sept. 1971).

Hierdie protes teen die opvoering is ook opgetel deur die Sunday Times (12 Sept. 1971) wat berig dat in Christiana en Bloemhof die plaaslike NG predikante, hulle gemeentes en die skoolrade, die stuk aangeval het en protesbriewe aan TRUK gestuur het. TRUK het geantwoord dat dit nooit hulle plan was om enigiemand te skok nie en dat die stuk pure satire was.

Verdere bewys van gesonde verstand het gekom uit 'n lang brief van R Engelbrecht van Pretoria (Die Transvaler, 16 Sept. 1971). Hy het die besware en aanvalle in die ander briewe in detail bespreek met verwysing na die stuk en daarop gewys dat dit goed is om vir mens self te kan lag. Hy eindig sy brief deur lesers te herinner dat Die hand vol vere 'n verwerking is van 'n stuk wat reeds in 414 v.C. geskryf is en spekuleer dat Aristophanes baie lekker sou lag as hy geweet het dat hy gemoedere sou kon laat opvlam selfs in die jaar 1971 n.C.! 
Dit is ironies dat ten spyte van die verontwaardigde reaksie teen die stuk al die resensente en protesteerders een baie sentrale aspek misgekyk het, en dit goed moontlik iets was wat werklik deur die Publikasieraad opgeneem sou kon word. Die naam wat André Brink aan die nuwe land gegee het, is nie Wolkekoekoekstad nie maar Kammabokmakierieland. Die kleure van hierdie land se vlag is swart, geel en groen, want die bokmakierie is 'n geel en groen voël met 'n swart dwarsstrook onder die keel. Dit is natuurlik ook die kleure van die ANC wat in 1971 nog 'n verbode organisasie was. Vir diegene wat die kleure en waarvoor hulle staan herken het, moes dit 'n verdere dimensie bygevoeg het elke keer as die koor 'Viva viva viva Kammabokmakierieland!' uitgeroep het. Hierdie vertoning was natuurlik net vir Blankes, want teaters is eers in 1977 vir almal oopgestel.

Nou kom ek by die derde voorbeeld, die van saterdrama of saterspel, die stuk wat geskryf is om na die trilogie van tragedies opgevoer te word en soos dit moet wees, laaste kom. Hierdie genre is die een waarvan ons die minste volledige stukke oor het. Trouens ons het net een min of meer volledige teks van so 'n stuk, nl. die Sikloop van Euripides. Ons ken egter die titels van baie ander van die stukke en het fragmente van 'n hele aantal van hulle waaruit ons kan aflei wat die struktuur en temas van die soort dramas was. Sentraal in elk was die koor van saters, halfmans halfbokke en volgelinge van Dionusos, die god van drama. Hulle is gelei deur Silenus. Die koorlede het dan ook 'n kostuum gedra met bok- of perdesterte, spits ore en 'n fallus. Dit is reeds 'n aanduiding dat saters se enigste doel in die lewe plesier is. Hulle word algemeen as lui en lafhartig uitgebeeld. 'n Drama oor hulle doen en late was waarskynlik 'n geskikte oorgang van die somber temas van tragedies na 'n vroliker atmosfeer geskik vir die fees.

Die saterspel wat ek gaan bespreek is Sophokles se Ichneutai (Spoorsnyers) waarvan 'n aansienlike stuk, amper 400 verse, op papirus in 1907 in Egipte ontdek is. Die onderwerp is die mite oor die geboorte van die god Hermes, seun van Zeus en Maia, wat op sy geboortedag die lier uitgevind het, Apollo se beeste gesteel het en Apollo se straf vrygesping het deur die lier aan hom te skenk. Die gebeure vind plaas by Hermes se legendariese geboorteplek, die berg Kyllene in Arkadië. Die teks begin met ' $n$ aankondiging van Apollo dat hy 'n beloning sal gee aan wie ookal sy verlore beeste terugvind. Silenus, leier van die saters bied aan dat hy en sy saters sal help. Apollo belowe dat hulle beloning goud en hulle vryheid sal wees.

Die saters begin soek, en vind gou hoefspore maar word verskrik deur 'n eienaardige geluid. Hulle geraas bring die plaaslike nimf, Kyllene uit haar grot. Sy vrees dat hulle haar kom aanval, maar hulle sê hulle wil net weet wat die geluid is. Sy verduidelik dat die pasgebore Hermes 'n lier gemaak het uit 'n skilpaddop. Dit is wat die vreemde klanke maak. Die saters is nou oortuig dat Hermes die beeste gesteel het want Kyllene het gesê dat beesvelrieme gebruik is om die lier te maak. Kyllene wie Hermes oppas in die grot sodat Hera, Zeus se vrou hom nie kan 
sien nie, wil hulle nie glo nie. Hier eindig die teks op die papirusfragment, maar verdere fragmente toon dat Apollo weer later in die drama verskyn. Waarskynlik was die klimaks van die stuk dat Hermes, reeds volwasse na ses dae, die lier aan Apollo skenk. Dit is hoe die verhaal in die Homeriese himne aan Hermes eindig.

Die Engelse digter en dramaturg, Tony Harrison, het hierdie fragment verwerk in 'n moderne drama, The trackers of Oxyrhynchus, wat die eerste keer in 1988 opgevoer is in die antieke stadion in Delphi. Ek sal eers kortliks aandui hoe Harrison Sophokles se teks uitgebrei het, aangesien Etman hierdie weergawe ook gebruik in sy verwerking van die saterspel.

Harrison kombineer Sophokles se karakters Apollo, Silenus, Kyllene, en Hermes met moderne historiese karakters, Bernard P Grenfell en Arthur S Hunt, papiroloë van Oxford wie betrokke was by die argeologiese opgrawings by Oxyrhynchus. Hulle het van die papiri ontdek, ontsyfer en gepubliseer, o.a. die fragmente van Sophokles se Ichneutai. Harrison se verbeeldingryke vermenging van historiese karakters met die mitiese figure van die oudheid is ' $n$ interessante benadering tot die verwerking van die klassieke drama.

In die openingstoneel van Trackers is Grenfell en Hunt, wat bestempel is as die Holmes en Watson van Britse papirologie, besig om papiri te sorteer en te verpak by die argeologiese terrein in Egipte. Hulle word gehelp deur 'n koor van 'Fellaheen', Egiptiese werkers. Grenfell se openingswoorde dui dadelik op die skakel met Sophokles se drama:

We're trackers (I $\chi v \varepsilon v \tau \varepsilon \varsigma)$ and what we seek are fragments of papyri in ancient Greek.

We've filled a few crates full already this week.

Here are treasures crated, waiting to be shipped

from Egypt back to Oxford, where we work out each script.

First we dig, then we decipher, then we must

deduce all the letters that have mouldered into dust (p. 9).

Hy verduidelik dan die geskiedenis van hoe die papirusrolle op die rommelhope ontdek is en dat die Fellaheen dit as kompos gebruik om groente te kweek. Hunt vertel dat Grenfell se vaardigheid in die onstsyfering van die geskrifte fenomenaal is, maar dat hy so begeesterd is en teen so 'n spoed werk dat hy soms vrees dat hy besig is om sy verstand te verloor. Hy verbeel hom dat Apollo met hom praat:

He heard Apollo yammering for scraps and tatters

Of some lost Sophoclean play called The tracking satyrs,

'Grenfell, Hunt!' he heard the voice abjure,

'Prevent Apollo's favourite play becoming mere manure' (p. 12). 
Hierdie aanknoping by die antieke drama word dan gevolg met 'n toneel waar Grenfell deur Apollo besete word. Die soektog na die verlore beeste word nou eers 'n soektog na die Sophokles-papirus. Harrison slaag daarin om die antieke en moderne te amalgameer. Hunt verander in Silenus en die Fellaheen in die saters. Sophokles se drama word dan as 'n drama binne die drama gespeel. Harrison sluit ook die toneel in waar Hermes die lier aan Apollo oorhandig en die god pragtige musiek daarop speel. Dit is so mooi dat selfs die saters ontroer word. Maar Apollo verbied hulle om te vertel hoe hy die lier in die hande gekry het. Hulle mag dit ook nie bespeel nie want dit is sy eksklusiewe eiendom. Die saters se beloning is ook nie die beloofde goud nie, maar blêrbokse (ghetto blasters) wat in goue foelie toegedraai is en 'n rock-styl verwerking van Apollo se liermusiek speel. Silenus lewer 'n sarkastiese monoloog waarin hy sê dat dit tipies is van die manier waarop saters behandel word. Hulle moet ander bedien maar mag nie aspireer om hulleself te verbeter nie. Maar, voeg hy by, vandag se saters is nie meer bereid om dit so te aanvaar nie. Daarop kom die saterkoor binne, nou geklee soos 'football hooligans'. Hulle sproei graffiti op die papirus en verbrand daarvan. In 'n oomblik van metateater pleit Silenus by hulle om nie die papiri te verwoes nie want dit is waarvandaan hulle kom.

Hierdie ietwat verrassende einde gee die drama 'n tema van bevraagtekening van wie die reg op kennis het. Apollo en Grenfell en Hunt maak aanspraak op die hoë en skone kunste, maar die saters voel hulle tyd het nou ook aangebreek, net soos die van die Fellaheen en ander onderdruktes, om in kennis te deel. Harrison se verwerking van waar die saters suksesvol is in die soektog en as koor by die Fellaheen oorneem, beklemtoon ook die rol van die gewone Egiptiese werkers in die herontdekking van die papiri.

Ahmed Etman het sy Arabiese verwerking met die titel Die bokke van Albahnasa gebaseer op Sophokles se teks asook Harrison se verwerking. Etman was Professor van Klassieke Tale aan die Universiteit van Kä̈ro. Hy het baie Griekse dramas in Arabies vertaal maar ook oorspronklike dramas geskryf. Ek baseer my vertolking van hierdie drama op die werk van Dr Mohammad Almohannah wat 'n doktorale student van my was in Nottingham. Ek maak ook gebruik van sy Engelse vertaling wat deur Prof Etman goedgekeur is.

Etman volg die struktuur van epiese drama wat bestaan uit 'n reeks van ses tablo's. Net soos Harrison voer hy ook historiese figure in as karakters, maar skep ook nuwe karakters. Die stuk open met 'n universiteitsvergadering wat belê is om 'n voorstel van Taha Hussein, rektor van die Universiteit, te bespreek, naamlik dat Grieks en Latyn as vakke aan die Universiteit van Kaïro ingevoer word. Ook by die vergadering is ' $n$ verteenwoordiger van die oudste Islamitiese Universiteit in Kaïro en twee Europese kenners van die Midde-Ooste, 'n Italianer, Carlo Nallino en 'n Duitser, Ludwig Littmann. Hierdie voorstel veroorsaak spanning tussen die 
konserwatiewe Islamitiese benadering dat veral hul eie kultuur bestudeer moet word, en die nuwe benadering dat daar meer kontak met Westerse kultuur moet wees.Taha Hussein was 'n groot voorstander van die belang van kennis van die Grieks-Romeinse oudheid vir Egiptenare en Etman beklemtoon sy rol deur hom as karakter in te voer.

Hussein was verantwoordelik vir die instelling van 'n Department van Klassieke Studie aan die Universiteit van Kaïro in 1925 (Etman 2007:143). Hy het beweer dat die geskiedkundige skakels tussen Egipte en Griekeland en die hele Mediterreense gebied uniek is en waarskynlik sterker is as die bande tussen Egipte en die ander lande van die Midde-Ooste. Etman het dus hierdie historiese gebeure met omtrent twintig jaar vervroeg en as deel van sy drama ingevoer.

Die tema van die belangrikheid van kennis word voortgesit in'n verdere toneel binne die universiteitsmilieu. Hierdie keer is dit 'n seminaar waar Hussein, Nallino en Littmann weer teenwoordig is. Dit gaan daarom oor inligting oor die opgrawings in Egipte, die belangrikheid van die kennis wat in die papiri gevind word en dat daar 'n tekort aan spesialiste in Egipte is om die papiri te ontsyfer die papiri moet dus na Europese museums weggeneem word. Daar word aangekondig dat die opgrawings voortaan onder toesig van die Egiptiese Raad vir Antikwiteite sal plaasvind en dat die fokus van opgrawings Oxyrhynchus sal wees. Hierdie naam is onbekend aan die gehoor, maar hulle herken die Egiptiese naam van die dorp: Albahnasa.

Die tweede tablo vind dan ook in Albahnasa / Oxyrhynchus plaas. Die toneel is ' $\mathrm{n}$ tradisionele koffiehuis, qahwah, naby die opgrawings. Dit vorm deel van die daaglikse lewe van die plaaslike bevolking. Die eienaar en een van die kelners praat oor die buitelandse ekspedisie wat kom opgrawings doen. Die dorpenaars moet regmaak om hulle te ontvang. Daar is 'n skerp kontras tussen die gesofistikeerde, geleerde karakters in die eerste tablo en die eenvoudige gemeenskap op die platteland waar baie waarskynlik ongeletterd is. Etman beeld hulle nietemin uit as slim en leergierig.

Die argeoloë verskyn ook in die derde tablo. Grenfell en Hunt, soos in Harrison se drama, is besig om die papiri te ondersoek. Die dorpenaars help hulle en ondertussen gaan die daaglikse dorpsbedrywighede om die koffiehuis voort. Later verskyn die Maghannawati, 'n tradisionele Egiptiese sanger. Grenfell merk op dat van sy liedere ook op 'n papirus uit die eerste eeu n.C. verskyn. So beklemtoon Etman die band tussen die hede en die verlede. Maar daar is ook gapings. Net soos Harrison, toon Etman dat die plaaslike bewoners, die Fellaheen, geen begrip het van die waarde van die papiri nie. Etman wys dat hulle die papiri as brandstof gebruik as hulle kook. Maar, natuurlik, as hulle deur die argeoloë vertel word hoe waardevol die papiri is, werk hulle hard om dit te vind. Intussen 
kom daar nuus dat die beeste van die plaaslike polisiehoof in die woestyn gesteel is.

In die vierde tablo bespreek Grenfell en Hunt die rol van Oxyrhynchus in die behoud van kennis van die antieke wêreld. Hulle word telkens onderbreek deur die leier van die opgrawingspan wat pas ontdekte papiri saambring. Hulle lees party van die papiri voor wat voorbeelde gee van die soort kennis wat daarin vervat is. Grenfell noem dat hy baie graag 'n papirus met Sophokles se saterspel Ichneutai sou wou vind. Dan praat hulle oor die diefstal van die beeste. Grenfell dink dit is deel van 'n plaaslike seremonie: die bokke van Albahnasa. Hy dink dit vind jaarliks plaas en dat die terugvind van die beeste aan die einde gevier sal word. Hy sê dit is ook die kern van die mite in Sophokles se saterspel. Etman se uitbeelding van die karakter van Grenfell as wetenskaplike is baie meer genuanseerd as die van Harrison. Etman beklemtoon sy belangstelling in die oorsprong van plaaslike tradisies en sy liefde vir sy werk:

Grenfell: Look Hunt, look how beautiful Oxyrhynchus is, this ancient town they now call Albahnasa.

Hunt: What on earth is beautiful about it? It is a dirty village, nothing but heaps of dung and sandy hills ... peasants, dumb beasts, bilharzia and mosquitoes!

Grenfell: No Hunt. The charm of Albahnasa lies in its history and its glory, in all the good it has offered humanity. It is a treasure of papyri, a treasure of knowledge, and don't forget, it is our bread and butter, the reason why we came here (p. 39).

Hierdie karakterisering van Grenfell pas by Etman se tema van die sentrale rol wat Egipte in die bewaring van die Klassieke beskawing speel.

In die vyfde tablo daag die beeswagter op en sê hoe spyt hy is dat die beeste gesteel is. Dan nooi die Maghannawati almal om deel te neem aan die Zar en Mendel seremonie waar gebid word dat die beeste weer gevind word. 'n Deel van die seremonie beeld die offerande van 'n bok uit en na afloop van die seremonie trek een van die deelnemers die bokvel aan. Volksliedjies word gesing deur 'n paar van die plaaslike bewoners. Daarna kom twee mans na vore. Hulle is die ouers van onderskeidelik 'n Christen dogter, Maria, en 'n Moslem seun, Mohammed. Die twee jong mense is verlief maar kon weens hul verskillende gelowe nie trou nie. Maria se vader belowe dat sy met Mohammed kan trou as hy die beeste kan opspoor.

Die verhaal van al Mohammed se avonture en hoe hy na die beeste soek, word dan in die sesde tablo deur die sanger vertel, voordat Mohammed self met die beeste opdaag. Grenfell hou kort daarna 'n perskonferensie waar hy aankondig dat 
'n papirus met die teks van die Ichneutai ontdek is en dat dit 'n beduidende bydrae tot ons kennis van saterdrama sal maak.

Etman se verwerking van die saterdrama is meer indirek want hy het geen saterkoor nie. Daar is slegs die offerande van die bok en daarna sing almal saam volksliedjies. Etman se doel is egter eerder om die kontinuïteit van die antieke Egiptiese kultuur tot in die hede aan te toon asook die bydrae wat Egipte lewer in die bewaring van die Klassieke oudheid, ook die Grieks-Romeinse kultuur.

Sowel Harrison as Etman het die tema van soek uit Sophokles se drama oorgeneem en uitgebrei. Waar Harrison die reg van elkeen op deelname aan kultuur en opvoeding na vore bring, brei Etman dit uit en beklemtoon dat die skatte van geleerdheid in Egipte nie net aan die wêreld behoort nie maar ook aan die Egiptenare wat dit deur die eeue bewaar het en in wie se tradisies aspekte van die antieke gebruike nog voortleef. Etman bring in sy drama ook hulde aan Taha Hussein en sy geslaagde kampanje om die studie van die Grieks-Romeinse oudheid ingevoer te kry in Egipte. Etman se eie suksesvolle loopbaan is natuurlik 'n produk van die nalatenskap van Taha Hussein en sy bevordering van die studie van die Klassieke oudheid.

Ek hoop dat hierdie drie voorbeelde van hoe die studie van die resepsie van Griekse drama temas in die moderne wêreld na vore bring, $u$ ' $n$ indruk gegee het waarom die Griekse drama deur die eeue, en vandag nog, dramaturge en gehore boei. Thyestes roer politieke en selfs ekologiese temas aan. Voëls gee vrye teuels aan die verbeelding en spot met politici en ander figure in die samelewing. Harrison en Etman se verwerkings van die fragment van Sophokles se saterdrama beklemtoon die aanspraak wat alle mense kan mak op die skatkennis van die antieke wêreld.

\section{BIBLIOGRAFIE}

Almohanna, M 2010. The reception of the Ichneutai in the modern Arabic world. New Voices in Classical Reception Studies 5 (www2.open.ac.uk/new voices).

Artaud, A 1961. Oevres Complètes 2 \& 3. Parys: Gallimard.

Brink, A P 1971. Die hand vol vere. Ongepubliseerde manuskrip.

Claus, H 1966. Thyestes. Amsterdam: De Bezige Bij.

Eliot, T S 1963. Seneca in Elizabethan translation. In Elizabethan Dramatists, 1157. London: Faber.

Etman, A 2000. The goats of Albahnasa. Ongepubliseerde vertaling deur M Almohanna.

Etman, A 2000. M'eiz Albahnasa. Cairo: Almarkaz Alhandsi. 
Etman, A 2008 Translation at the intersection of tradition: The Arab reception of the Classics. In Hardwick, L \& Stray, C (eds.), A Companion to Classical Receptions, 141-152. Oxford: Blackwell.

Hardwick, L 2003. Reception Studies. Oxford: OUP.

Harrison, T 1991. The trackers of Oxyrhynchus. London: Faber.

Lloyd-Jones, H 1996. Sophocles III - Fragments. Cambridge, Mass: Harvard University Press.

Sommerstein, A H 2002. Greek drama and dramatists. Routledge: London.

Tarrant, R J (ed.) 1985. Seneca's Thyestes. Atlanta, Georgia: Scholar's Press.

Van Rensburg, J P J 1959. 'n Oorsig van die oud-Griekse letterkunde. Stellenbosch: UUB.

Van Zyl Smit, B 2005. Aristophanes in South Africa. SATJ 19.1:254-276. 